\title{
Claudel, Vézelay and the Pilgrim Experience
}

\author{
Larissa Juliet Taylor \\ Colby College
}

My guide made me notice how frequent, in this church consecrated to the memory of the Penitent, were images of spiritual combat... I applied my lips one last time on the relic of the Magdalen, and I left... (Claudel, "Vézelay," CEurres en prose, 320,322 ).

I came to the works of Paul Claudel by a circuitous path. I knew of his sister Camille from the film, but as a medieval religious historian, I had had no reason to encounter his works until I began extensive research on medieval and contemporary pilgrimage to the village and basilica of Vézelay. As my research broadened, I was struck by the constant references to the luminaries-writers, artists, critics, lovers-who had passed time in the small Burgundian village of 450 souls. One guidebook called Paul Claudel the greatest poet of Christianity, then went on to speak of his love for Rosalia Scibor de Rylska:

... Claudel fell hopelessly in love. Without her, Claudel would not have written either Partage de Midi or Le soulier de satin. Without her, there would never have existed the character of Ysé or that of Dona Prouhèze, wonderous and immortal representations of woman in literature and theatre. It was Rosalia who, with Magdalene, transformed the rock of Vézelay into a land of passion (Roy, 34).

I "discovered" Vézelay as part of my study of Mary Magdalene in late medieval preaching (Taylor, 174-8), but on later visits I focused on the basilica as a medieval pilgrimage site in its own right and as part of the route to Compostela. Between my first visit to Vézelay and my most recent, I had undergone a conversion experience that began on 


\section{Larissa Juliet Taylor}

Christmas Day 1996 in Dijon and culminated in 2000. Paul Claudel was not part of my life or study then, so I did not know that my experience happened exactly 110 years after his. Vézelay changed my heart. As I increasingly focused on notions of journeys, life paths, and sacrality of space, I was struck by the repeated mention of others who had found inspiration there. The most recent included Picasso, Braque, Giacommetti, Bataille, the Zervoses, Romain Rolland, Max-Pol Fouchet, Henri Petit and-Paul Claudel. If I wanted to understand my experience of this, my place, I had to read their writings. In Claudel I discovered the emotional, poetic and religious underpinnings of my feelings, yet not in the expected places.

Claudel visited Romain Rolland in Vézelay in April 1940; he wrote his short-very short-essay, "Vézelay" in 1948. After reading much of his poetry and prose, I read the essay and can only describe the experience as cold and sterile, far different from the moving and emotional words of discovery and conversion that echoed throughout his other writings. $\mathrm{He}$ mentions the last kiss on the lips of the Magdalene and speaks of her radiant soul, but the essay is in essence a tribute to the stunning capitals. But in that reference was a clue. The beautiful Romanesque capitals feature Biblical and mythological scenes, many of which focus on spiritual combat. One capital focuses on the sins of Lust and Despair. Yet I still could not fathom the relative aridity of Claudel's prose descriptions of this magnificent place, which encompasses pilgrimage, journey, darkness, light, sin, despair and hope. I have been there in every season of the year liturgically and seasonally, and each has been a revelation. It has had the same effect on many others. How could it have made so little impression on someone whose poetic and literary talents were so great? I will offer the tentative answer of someone who knows almost nothing of Claudel, but something about both Catholicism and psychology.

The guidebook provided what historians refer to as negative evidence, for Jules Roy asserted that it was Claudel's love Rose who had transformed the rock of the basilica into an earthly landscape of fire and passion. Yet his human, erotic, and forbidden love for Rose was an expression of belief in something greater. On her tomb in the cemetery at Vézelay are words from Claudel's Cent phrases pour éventails: "Seule la rose est assez fragile pour exprimer l'étérnite [Only the rose is fragile enough to express eternity] (Claudel, CEuvre poétique, 724)." In another poetic phrase, Claudel laments: "The rose is planted in the ground and the chrysanthemum is grown in the mist" (Claudel, Euvre poétique, 


\section{Claudel, Vézelay and the Pilgrim Experience}

761). Jules Roy adds, "but Rose was not on the altars. Only in the earth... It awaited Henri Petit, another spirit who fell hopelessly in love with Vézelay [to express the sentiment]: 'an eternal place battered by the winds"' (Roy 34). For Max-Pol Fouchet, "Vézelay [was] memory" (quoted in Murray, 22).

Roy's words forced me to ask new questions about what this place had done to me as well as others, so I began reading their works and studying their art, trying to find my own reasons for transformation. Nothing fit my experience until I read the prose and poetry of Claudel. I was struck by how much many of his poems and essays seemed to embody the ephemeral yet earthy spirit of Vézelay. In "Connaissance du temps," Claudel cries,

It is why the sun, stopping itself, catches fire in the middle of the world, ecstasy in violence! like a lamp that is lit, like someone who looks on all sides to find out where he is (Claudel, CEure poétique, 137).

In his Feuille des saints to Sainte Cécile, he captures the feeling of season that is Vézelay:

The feast of Saint Cecilia is celebrated in the month of November,

and like the fruits of autumn, end by ripening when one takes them inside.

It is a time of wagons filled with people whom we see discharged at the portals of our basilicas.

Drums, trombones, bass violins, flutes, and all the musical instruments...

Cecilia, before all the flowers, was the first bird who sang,

Three notes only, so it is said! listen, winter is over,

The horrible pagan winter, the sadness of that which is dead and rotting (Claudel, CEure poétique, 615-6).

He begins his feuille for Sainte Colette, with the following words:

At the hour when in the mists of the north, the scarlet sun rises... 


\section{Larissa Juliet Taylor}

Nature at the back of a hillside all by itself reproduces a magnificent lily! (Claudel, Euvre poétique, 621).

But I wondered even as I began to read his poems why there was no feuille for Sainte Madeleine? She is frequently mentioned in other works of prose and poetry, always in a religious context, away from Vézelay where her relics are venerated. I think I have come to know the answer.

It is in his Cent Phrases pour éventails, inspired by his time in Japan and China, I find the seasonal aspects of Vézelay most fully expressed. Some excerpts appear as true of the Burgundian countryside as of the Far East:

A ray of sunlight caught in a swirl of snow

Quickly a teardrop, crossing a ray of sunlight; it is gone

The end of August, in the fog amidst thousands of dragonflies three white butterflies

A window at sunrise that opens on the white fog to a country of embers and fire

Four o'clock in the morning, the color and the light of the sun and the moon mix together like water with wine (Claudel, CEuvre poétique, 733, 735, 737, 739, $745,750)$.

Such citations could be multiplied indefinitely, but my first reaction to opening almost any page of Claudel's work by saying it was Vézelay.

What is Vézelay? A photographer there echoing the words of Petit, once told me it was le vent de l'esprit - the breath or wind of the Spirit. I have gone to la colline éternelle in all seasons-the beautiful spring of vineyards and golden sunlight sparkling off the rooftops; the summer solstice, when the sun traces footsteps to the altar; the autumn when the darkening days cast a pall over the village and chill strikes the air. Fog and mist rise from the Cure Valley to envelope the hillside. Most of all I have gone there in winter, for it is then that you come to know Vézelay. Edith de la Héronnière describes it as follows:

The winter village is more familiar to me in the asceticism of the leafless trees, in the somber faces of the stones that have been blackened by the torrents of rain; the streets are deserted; the geraniums have been taken 


\section{Claudel, Vézelay and the Pilgrim Experience}

from the windows; all the doors of the boutiques are closed with wooden shutters... The wind of revolt has not ceased to breathe like the four winds... The seven demons are in permanent residence... The devils are outside. The demons are inside... (de la Héronnière, 144-45,150).

My first few pilgrimages to Vézelay occurred in spring, summer and fall. I fell in love with the place, and the steps I took up the hillside and in the basilica walked me tentatively toward my Creator. Francis Salet insists that

the religion that this architecture expresses is not austere, nor even demanding; everything here exudes sweetness and forgiveness... The soul... can only awaken and be brought to prayer before the grandeur of the landscape of Vézelay which, from all directions, undulates in great waves, rises and falls again, and surging from the horizon, bows at the feet of this jetty battered by all the winds of heaven and earth (quoted in Murray, 6-7).

That was my first feeling of Vézelay-the austere, ugly exterior, the narthex with its beautiful capitals, then the flood of light as the doors open to the nave and the Gothic choir. Yet here too is the hint of Vézelay's violent history. In 1104, the abbot Artaud was murdered by villagers for his taxes; in 1120, on the eve of the Feast of Mary Magdalene, when pilgrims were crowded in the church, a great fire broke out, killing about 1200 people. This led to the addition of a Gothic choir in the beautiful pink and blonde Romanesque church. On the hillside, where a cross was erected in 1899, Bernard of Clairvaux preached the Second Crusade. Great kings met there to embark on later crusades. The village engaged in what might be termed a holy (and economic) war with $\mathrm{La}$ Sainte Baume in Provence over who possessed the authentic relics of Mary Magdalene. Vézelay lost, although the spoils would later be divided. The great architect of Protestantism in France, Theodore Beza, was born in Vézelay. These are only a few examples of a village history that is filled with violence and hatred. Perhaps that is why Claudel focused on the capitals, which with few exceptions depict scenes of hor- 


\section{Larissa Juliet Taylor}

ror and Biblical sin. But it is also a place specially graced by sunlight that dances up to the altar and sparkles off the cross, a town where lilacs, geraniums and chrysanthemums assault the eyes in a dance of color and fragrance. Magdalene, the erotic and deeply faithful woman, is still present. Yet for all the human failings embodied in the town, it is more than that, something that attaches itself to the human spirit:

The village appeared surreal-near and far at the same time-in a visual foreshortening. Thus it resembles the city of Arezzo painted in the fresco of Piero della Francesco: a great body of stone presiding over the destiny of human beings. (de la Héronnière, 21)

Edith de la Héronnière goes on to describe the ephemeral nature of Vézelay according to season:

she was bowled over... by the asymmetry, the sea of fog that rises from the river Cure, making fluffs of cotton, the blasts of wind, the tempests that are like diabolic screams... (de la Héronnière, 108).

That is what I experienced when I spent the week between Christmas and New Year's there. Only one hotel was open-La Compostelle - and there were no tourists, only a frigid cold that reminded me of one of Claudel's letters to Arthur Fontaine:

It is splendidly cold, one breathes in whipped sunshine. The cold is what ties up everything, what reduces everything to its maximum of astriction and tension; what tunes the harp strings. How full of stars the nights and how one feels life approaching the mysterious moment of the solstice when this year finishes in great secrecy... (Claudel, in O'Connor, 111).

The Jerusalemites celebrated mass in the basilica's wing chapel; locals shielded their faces from the icy temperatures and winds. Soon after I arrived, an ice storm hit. I walked the path of Compostela to the nearby town of Saint-Père-sous-Vézelay, where I inched my way at the rate of about a foot every five minutes, clutching frozen branches for sup- 


\section{Claudel, Vézelay and the Pilgrim Experience}

port. The paths diverged and I was unsure which to take; a sign warned me to beware of snakes, although the hotel proprietors insisted they were frozen or hibernating. When I walked with equal difficulty past La Cordelle to the cross of St. Bernard, which had sparkled in springtime sun, I found a snowy and icy hill that beckoned dangerously. The Gothic choir of the basilica was purple, not golden. The cemetery in which Rosalie Scibor de Rylska Vetch is buried under a black iron cross, was grim. The weather worsened until New Year's Eve. On December 30, there was a rainstorm like none I have experienced. I opened the windows of my room to be pushed back in by torrents of rain and wind. Again I felt the words of Claudel from his Postcript to On Art and Ecce sto ad ostium et pulso:

By means of night it must be given us to dwell in Light. ... But instead of light shining from the golden walls on the interior of the building, here it is from the very centre that it emanates, like the conscience awakening... No longer is it the space about us which sets us our point, it is ourselves that create space... Whilst I listen to the frightful storm which even now is shaking my whole house, I cannot help thinking of that verse of the Apocalypse: "BEHOLD I STAND AT THE DOOR AND KNOCK.... God does not knock merely, HE PUSHES. Sometimes a violent push, a thorough test of our resistance... He unceasingly assaults and ever, everywhere... (Claudel, in O'Connor, 178, 203-4).

How could the basilica that had stood for 1000 years possibly withstand the force of such a tempest? I had another thought-that these were the uncontrollable tears of the Magdalene in the garden as she wept for her lost Jesus. The moon appeared in the middle of the night, surrounded by wispy clouds that recalled the scallop shells of the pilgrims. The moon figures in many of Claudel's works, the sun of the night that symbolizes the spiritual and the sensual. Analyzing Le soulier de satin, Joan Freilich writes:

The fulfillment that Rodrigue experiences during this brief encounter with Prouhèze is thus both spiritual and erotic in nature, and the Shadow's accusation underscores 


\section{Larissa Juliet Taylor}

on the narrative, religious and emotional levels of the text simultaneously the gravity of the transgression he has committed.

The manifold consequences of this violation of social, religious, and moral codes are revealed by the Moon... After explaining that the lovers have separated once again, the Moon quotes their words as each grieves over the loss of the other... On the narrative level, the imagery of these lines evokes the great distress Rodrigue will experience while he is separated from his beloved; the anguish suggested by the references to death and night is reinforced by the more detailed description of this torturous state in terms of the Crucifixion.

On the religious level, the Cross-code imagery indicates the sorrow and frustration Rodrigue will experience as a result of his decision to leave Prouhèze at Mogador will serve as his own personal Crucifixion, a painful experience through which he can atone for the sins he has committed by his desires for a woman (Freilich, 120-1).

In The Seven Last Words, Claudel captured the moment:

When the hour of midnight is passed, that summit of time is the center of the sidereal fullness, and when turning on its axis, the double index of duration begins to bend and descend toward that nadir which is daybreaksix in the morning-the watcher becomes conscious in himself of an operation which was destined morally to have sleep as its only witness (Claudel in Fowlie, 129).

The next morning it was dark when I walked to the basilica for morning Psalms, but when I emerged it was into blinding sunshine and blue sky. It was the eve of a New Year.

This is my background to reading Claudel's "Vézelay" and my great disappointment in it. How could the man who had written prose and poetry about other subjects that so perfectly embodied Vézelay have written what to me is a dry, short and unemotional essay? He had been there. And his other works repeatedly came back to the image of a repen- 


\section{Claudel, Vézelay and the Pilgrim Experience}

tant, faith-filled, loving and tearful Magdalene. In The Seven Last Words, he moves from the visible to the invisible:

Let us leave Magdalen at the foot of the cross, blazing in the realization of the holocaust, let us allow that crater of perfume loudly to emit the despair and love under the blood which rains on her drop by drop; and let us leave to their sorrow today with that humble sinner who sobs deeply... The sun is no longer in the sky... For love, everything is combustible (Claudel, in Fowlie, 131,138).

Although I know little of the life of Claudel except what I recently studied, I would like to suggest a psychological explanation that is part of every pilgrim's experience. Claudel may or may not have described himself as such, but it fits, not only because a religious journey is a pilgrimage, but because his travels as a diplomat exposed him to many different places and beliefs. A religious convert, almost by definition, is filled with more zeal than someone who has always been part of a faith. Although Claudel's family was Christian, he had not practiced until the famous conversion experience at Notre-Dame at Christmas mass in 1886. For the convert, while this is a beginning, it also seems like an ending. Things are now certain; you are on the right path.

But life does not work that way, and human beings are imperfect, as Paul Claudel found out in 1900 when he embarked for China. On the boat he met Rosalie or Rose Vetch, a married woman with four children. Their relationship lasted four years, resulting in the birth of their daughter Louise in January 1905. But Rose broke off the relationship for another man whom she married after her divorce. One month after the birth of his daughter and thirteen months before his own marriage, Claudel began Partage de Midi, a work most believe is autobiographical, with Ysé representing Rose, and Mesa the author. Its subject was sin, good and evil, and some see in the three versions an attempt to rewrite his life. Partage was a cry of shame:

The carnal liaison he is on the point of entering into is as far a cry as possible from his recently refused vocation. Revenge against his God? Guilt invades him. ...The whole of "Le Cantique de Mesa"... is another highspot in Claudel's literature, recapturing the playwright's tortured 


\section{Larissa Juliet Taylor}

état d'âme as he resolves intellectually what his weak flesh cannot accept (Waters, 78-9).

What, you might ask, does this have to do with Vézelay, except for the fact that Rose lived in nearby Avallon, and was buried in the cemetery at Vézelay four years before Claudel's death? Although Ysé comes to represent a figure like Dante's Beatrice, a muse who puts him back on the path to God, the rupture of their affair cannot be so easily dismissed for someone who had experienced a profound conversion experience. I think the reasons for Claudel's tepid, short, purely artistic response to the place where the wind of the Spirit resides lays in what the basilica stands for and his relationship with Rose. For this was the church of Mary Magdalene, viewed for most of her history as the repentant prostitute who first witnessed the Risen Christ. The darkness and light, the sin, despair and hope that are represented in the capitals of the basilica, the history of the town, and its violent and changing seasons, were, I would suggest, too raw for Claudel. The Magdalene, the proximity of Rose, this village of endless contrasts of good and evil all would have revived his pain, shame, and intense love for a woman, all at the expense of the God he claimed to love above all. He wrote of the interdependence of divine and profane love, but I would suggest he could not handle the consequences of his greatest human love. When he kissed the lips of Mary Magdalene that last time before leaving the basilica, who was he kissing? A profoundly religious man, Paul Claudel could only feel the agony of his sin and his lost love. Who better to epitomize both than the repentant woman who was first witness to the Resurrection? Was Vézelay too painful a reminder of the many types of love betrayed? In A Poet Before the Cross, Claudel says as much: "This is the royal ampulla, broken and streaming from the fingers of the Magdalen, like an opened rose, like a heart bursting.... (Claudel in Fowlie, 4) This work offers many concrete representations of Claudel's spirituality:

Visible things must not be sundered from things invisible. Both together make up the Universe of God and have mutual relationships clear or mysterious; indeed, the Apostle tells us that by the one we are guided to a knowledge of the others... For the simple flight of a butterfly you need a whole sky. You cannot understand a 


\section{Claudel, Vézelay and the Pilgrim Experience}

daisy in the grass if you do not understand the sun among the stars (Claudel, in O'Connor, 4-5).

In On Art, Claudel enunciated the theme that I believe he found in his forbidden Rose: "We live to comprehend. We have to decipher on all creatures the signature of the Creator, the praise of which he has to $t$ ell us of good... It is a question of shutting out nothing, of gathering all together, of utilising the whole vocabulary at our disposal... (Claudel, in Fowlie, 161).

The Magdalene who is omnipresent throughout Claudel's other works is curiously supplanted by images of combat, deadly sin, and despair in his description of the capitals at Vézelay. The answer, in my naive view, is to be found in his relationship with Rose. She was the visible expression of his spiritual longing, and yet represented both love and sin, much like Mary Magdalene. As with the Magdalene's love for Jesus, which followed her legendary love of so many mortals, Claudel found himself reflected in Rose: "A flame takes root in what is inextinguishable in us, and gives expression and eloquence to our natural totality and sheds out light in all directions (Claudel, in Fowlie, 257). In The Seven Last Words, he writes "And it is on the bare shoulder of the Magdalen that He wanted to reach the ground....What in truth is more hermetically closed and compressed than a walnut? Inside, it is attached with all its strength to its own shell. To open it, you have to break it; in order to bring out from its wooden coffin the edible mummy... (Claudel, in Fowlie, 189, 210)" For Claudel, Rose represented life and death. So too, I would argue, did Vézelay. Edith de la Héronnière understands the place as well as any contemporary writer:

It is an affair of passion. Almost all who arrive [at the summit of Vezelay] fall in love with it. They are jealous of this place so unique that each person believes to have discovered the truth... The absolute brings to life the real. Under its auspices, death is ever present. ...The brutality of death has been revealed to me, but there too it has given me the opportunity to assimilate all the wounds and the losses in order to reassemble the spare parts of my life and to gather there the most intense moments of friendship. (de la Héronnière, 156, 159-60). 


\section{Larissa Juliet Taylor}

Vézelay is a place where each creative spirit finds meaning, but sometimes that meaning is too much for a human being to bear. For Claudel, reducing Vézelay to its artistic grandeur was a means of dealing with a pain and shame too great to bear.

\section{References}

Claudel, Paul. CEuvres en prose. Dijon: Bibliothèque de la Pléiade, 1965.

Claudel, Paul. CEurre poétique. Dijon: Bibliothèque de la Pléiade, 1962.

Claudel, Paul. A Poet Before the Cross, trans. Wallace Fowlie. Chicago: Henry Regnery, 1958.

Claudel, Paul. Ways and Crossways, trans. Fr. John O'Connor. Freeport, NY: Books for Libraries Press Inc., 1933, repr.1967.

Freilich, Joan. Paul Claudel's Le soulier de satin: A stylistic, structuralist, and psychoanalytic interpretation. Toronto: University of Toronto Press, 1973.

Héronnière, Edith de la. Vézelay: L'esprit du lieu, essai. Paris: Pygmalion, 2000.

Murray, Kevin. Memory and Modernity: Viollet-le-Duc at Vézelay. College Park:

Penn State Univ Press, 2000.

Roy, Jules. Vézelay guide sentimental. Vézelay: LOOr des Étoiles, n.d.

Taylor, Larissa. Soldiers of Christ: Preaching in Late Medieval and Reformation

France. Toronto: University of Toronto Press, 2003, pb. repr., originally

published by Oxford University Press, 1992.

Waters, Harold A. Paul Claudel. New York: Twayne Publishers, 1970. 